confirmed the close relationship of the Criollo and Forastero cultivars and South American wilds ${ }^{5,6}$. These data imply that cacao cultivations of the Maya do not exist in modern germ-plasm collections. Managed groves were probably abandoned after European colonization, with a few remaining in isolation, protected by the Maya descendants. Rediscovered populations in Mexico are either derivatives of previously undetected wild cacao or remnants of ancient cultivars of the Maya people. The occurrence of the Yucatan 'wild' accession in known Maya 'sacred groves' supports the latter suggestion.

\section{Marlene de la Cruz}

Centro de Ecologia,

UNAM Apdo, Postal 70-275,

CP 04510 Mexico City, Mexico

Richard Whitkus

\section{Arturo Gómez-Pompa}

Department of Botany and Plant Sciences, University of California,

Riverside, California 92521, USA

Luis Mota-Bravo

Department of Ecology and Evolutionary Biology,

University of California,

Irvine, California 92717, USA

\section{Tuatara sex} determination

SIR - Temperature-dependent sex determination (TSD) exists in three orders of living reptiles ${ }^{1-3}$. Here we report evidence that both surviving species of a fourth order (Sphenodontida) also exhibit this phenomenon. This finding is important to the conservation of sphenodontidans, and increases confidence in the suggestion that TSD is the ancestral sex-determining mechanism in reptiles ${ }^{4}$.

We suspected that the lizard-like reptile tuatara (Sphenodon punctatus) exhibited TSD after observing total sex biases among locatable offspring for three zooincubated clutches. We subsequently sexed juvenile $S$. punctatus remaining in New Zealand from experiments in 1986 in which wild eggs were incubated under controlled conditions ${ }^{5,6}$. Live offspring were sexed by laparoscopy and available carcasses by dissection and/or histology. Incubation temperature had a highly significant effect on sex $(P=0.001)$. Sex ratios (F:M) were $9: 0$ at $18{ }^{\circ} \mathrm{C}, 31: 3$ at 20 ${ }^{\circ} \mathrm{C}$ and $4: 13$ at $22^{\circ} \mathrm{C}$, temperatures within the range experienced by natural nests ${ }^{7}$. Although $32.4 \%$ of eggs failed and were unsexed, differential mortality of sexes pre-hatching is, as in other reptiles, unlikely to explain the results. At $20^{\circ} \mathrm{C}$, for instance, 83/115 eggs hatched and among 34 that hatched $91.2 \%$ were female. If we assume this sex ratio for all 83 hatchlings and also assume the extreme case of all dead embryos being male, the calculated sex ratio (76 F: $39 \mathrm{M}$ ) is still significantly biased $(P<0.001)$. Differential mortality post-hatching is unlikely, as sex ratios at $20^{\circ} \mathrm{C}$ show a female bias both in juveniles sexed live $(23: 2 ; P<0.001)$ and in those sexed dead $(8: 1 ; P=0.04)$.

Data from an egg-incubation programme generating $S$. guntheri for reintroduction to the wild ${ }^{9}$ also suggest that TSD exists. Wild eggs were incubated halfburied at $-430 \mathrm{kPa}$ and at 18 or $22^{\circ} \mathrm{C}$ or a variable temperature regime (mean temperature $19.8-20.6^{\circ} \mathrm{C}$; temperature varied gradually over $18 \rightarrow 23 \rightarrow 18{ }^{\circ} \mathrm{C}$ during incubation). Overall hatching success was $88.0 \%$. Sex ratios (F:M) among dead juveniles (live offspring were too small for laparoscopy) were $17: 0\left(18^{\circ} \mathrm{C}, P<0.001\right)$, 3:0 $\left(22^{\circ} \mathrm{C}, P=0.250\right)$ and $0: 7$ (variable, $P<0.02)$. The male bias under the variable regime may result from temperatures $>22^{\circ} \mathrm{C}$ for at least 2 weeks in the middle of incubation, which in other reptiles is within the temperature-sensitive period ${ }^{1}$. Both species exhibited $100 \%$ females at 18 ${ }^{\circ} \mathrm{C}$ and a tendency towards males under a warmer regime(s). These observations fit the type $\mathrm{Ib}^{2}$ or $\mathrm{FM}^{1,10}$ pattern of TSD in reptiles, though further studies are necessary to rule out a type II (FMF) pattern ${ }^{3}$.

In rare sea turtles, some incubation practices performed without knowledge of TSD have apparently resulted in malebiased sex ratios of reduced benefit to conservation $^{11,12}$. Tuatara are restricted to 30 offshore islands of New Zealand ${ }^{13}$. Fortunately, the range of temperatures used in incubation programmes for both species has resulted in an estimated $68-77 \%$ of offspring being female, a favourable ratio for conservation purposes.

\section{Alison Cree}

Department of Zoology,

University of Otago,

Box 56, Dunedin, New Zealand

Michael B. Thompson

Department of Zoology (AO8),

School of Biological Sciences,

University of Sydney,

New South Wales 2006, Australia

\section{Charles H. Daugherty}

School of Biological Sciences,

Victoria University of Wellington,

Box 600, Wellington, New Zealand

1. Lang, J. \& Andrews, H. V. J. exp. Zool. 270, $28-44$ (1994).

2. Ewert, M. A. \& Nelson, C. E. Copeia 1991, 50-69 (1991).

3. Viets, B. E. et al. J. exp. Zool. 270, 45-56 (1994)

4. Janzen, F. J. \& Paukstis, G. L. Q. Rev. Biol. 66, 149-179 (1991).

5. Thompson, M. B. Resp. Physiol. 76, 243-256 (1989).

6. Thompson, M. B. J. Zool. 222, 303-318 (1990).

7. Thompson, M. B., Packard, G. C., Packard, M. J. \& Rose, B. J. Zool. (in the press).

8. Hutton, J. M. J. Zool. 211, 143-155 (1987)

9. Cree, A. et al. Contr. Herpet. 11, 377-385 (1994)

10. Ewert, M. A., Jackson, D. R. \& Neison, C. E. J. exp. Zool. 270, 3-15 (1994)

11. Mrosovsky, N. Biol. Conserv. 23, 309-314 (1982).

12. Wibbels, T. R. et al. Proc. 1st int. Symp. Kemp's Ridley Sea Turtle Biology, Conservation and Management Galveston, Texas (eds Caillouet, C.W. \& Landry, A. 77-81 (Sea Grant College Publ., Galveston, Texas. 1989).

13. Daugherty, C. H., Cree, A., Hay, J. M. \& Thompson, M. B. Nature 347, 177-179 (1990).
Mouse knockouts rule OK

SIR - The value of genetic analysis to the study of learning and memory, specifically the value of mouse null mutants, has recently been questioned by $\mathrm{A}$. Routtenberg in Scientific Correspondence (Nature 374, 314-315; 1995). The objection was raised that mice harbouring null mutations are "reactionisms" (sic): another gene product, or system of gene products, may compensate for the missing gene product. As a consequence, data generated in the analysis of null mutants may be uninterpretable, presumably because of the complex interactions among the many genes involved in learning and memory.

The objection is based on the ill-founded assumption that an inability to observe a phenotype must mean that there is no phenotype to observe. But the maintenance of a gene is prima facie evidence that its absence would occasion a decrease in fitness (a phenotype), though not necessarily one easily observed under limited laboratory conditions. This mistake was compounded by overstating the significance of the synergism between mutations that frequently produces new phenotypes: this is not a novelty of mouse genetics, but a common occurrence even in Escherichia coli.

Complex biological processes will have complex genetics. This truism can easily be illustrated by considering mutations in E. coli: mutations affecting the catabolism of lactose define a relatively simple genetic pathway, whereas those affecting the doubling time of $E$. coli on rich medium would define an extremely complicated genetic system. Only in such simple pathway systems as intermediary metabolism can we expect simple genetic pathways; as learning and memory in mammals are among the most complex of biological processes, we can only expect their genetics to be complex.

We should not abandon genetic analysis because of its unwelcome message that learning and memory are more complicated than our heuristic theories allow. Nor should we hope that genetics or some future method of analysis will effect a miraculous simplification of these processes. Rather we should make use of, and integrate, data from all available methods. In the interplay between the production of mutants and their phenotypic analyses, our ability to generate mouse mutants has clearly outstripped our ability to analyse their phenotypes. We are especially in need of more refined methods for studying neural processes in mice.

\section{U. Hochgeschwender}

M. B. Brennan

Unit on Molecular Genetics,

National Institute of Mental Health,

NIH, Bethesda, Maryland 20892, USA 